\section{Biology and Health}

AT the twenty-sixth annual general meeting of the British Social Hygiene Council, the president, Sir Walter Langdon-Brown, took for his subject the relation between biology and health. This address has been printed in the current issue of the organ of the above Society, Health and Empire. As an introduction he described the attempts that have been made by certain countries to degrade all the standards of learning and to stultify the search for scientific truth. Quoting from this year's report of the Rockefeller Foundation, Sir Walter explained how, all over Europe, the activities of the Rockefeller Foundation have been brought to"a standstill. "The conception of knowledge as an international responsibility has vanished . . as German forces have moved from one country into another a definite pattern has been followed." Where this was resisted, faculties were sent to concentration camps and student demonstrations were broken up with machineguns and tanks. The rest of this story is too familiar to need reiteration. In 1932, Pflugers Archivs, the outstanding publication for seventy years in physiological and biological research, ran to five volumes. In 1938 it appeared as one slim volume. The Münchener Medizinische Wochenschrift, formerly one of the leading weekly medical journals in the world, has now become the happy hunting ground of cranks and naturopaths who hope to catch the Führer's eye. Yet the lamp of learning will never be extinguished, and Sir Walter went on to deal with particular examples of the way in which biology has made for improved conditions of health. The well-known work of the Rockefeller Foundation in controlling the spread of Anopheles gambice after its introduction to Brazil from Africa in 1930, and its almost complete -if not completo-eradication by 1940 was one of the more important examples that were considered.

Later, Sir Walter described the steps that will have to be taken to combat the ravages of venereal diseases. Although the causal organisms of these diseases have been known for many years, there is still in existence the 'hush-hush' policy which refuses to admit the cleansing light of understanding. The traditional opposition of the Victorians to any mention of sex matters in polite circles initiated a conspiracy of silence which is long a-dying. But this silence is being confronted by freer and franker discussion of sex matters among all classes. In this connexion the introduction of biological subjects with its objective approach to the study of reproductive physiology, in many schools and colleges, has played a noticeable part. The three main planks in the platform of the British Social Hygiene Council were outlined as follows: (I) The study of biology as a subject of general education ; (2) the education of the educator; (3) general enlightenment on the principles of social hygiene. The remainder of the address was devoted to an amplification of these three problems and an account of the manner in which the British Social Hygiene Council is trying to grapple with them. A most heartening feature of the address was the statement that there has been no sensational rise in the incidence of venereal diseages in this War as there was in the last.

\section{The University of Liverpool}

THE annual meeting of the Court of the University of Liverpool was held on November 27, the Chancellor (the Earl of Derby) presiding. Lord Derby paid a high tribute to the work of the University throughout a difficult year in which the University. buildings suffered considerably by enemy action. He recorded with pleasure, however, that the loss of life was fortunately slight, and that despite all difficulties, study has been maintained on a high standard. Sixty. five members of the teaching staff are now serving with the Forces or in Government Departments ; the Senior Training Corps is strong ; and the Air Squadron has grown considerably. The work of the Women's Training Corps has prospered, and the basic training in social service is well advanced. Thanks to the generosity and friendship of the City Council, the University is now receiving an annual grant which has reached the total of $£ 25,000$. By the generosity of Messrs. J. Bibby and Sons, the University has now been able to establish in Wirral a Veterinary Field Station under Prof. J. G. Wright.

The coming retirement of Prof. E. W. Marchant from the chair of electrical engineering was announced at the meeting. Mr. R. H. Armstrong, pro-chancellor, detailed the progress of the regionalization of the voluntary municipal hospitals, in which the University should become a focal point. He paid tribute to the research work of the University, affirming that through it, the national effort has received and would continue to receive a handsome dividend. His analysis of income and expenditure showed that the University finances are sound and that war conditions have imposed no undue burden upon student finances. The vice-chancellor (Dr. A. D. McNair) submitted his annual report, in which he emphasized the expansion of the Senior Training Corps and the part played by women students in national service. All women students were now required to engage in part-time national service.

\section{British Standards Institution}

The British Standards Institution announces that, in view of the continuing expansion of the work of the Institution and the development of its relations with the Government Departments and with standardizing authorities overseas, the General Council has appointed an Executive Committee under a permanent chairman. The Executive Committee will keep all the activities of the Institution under review and report to the General Council from time to tirne as may be necessary. Mr. C. Ie Maistre, who has been connected with the movement almost since its initiation, and who for the past twenty-five years has been its chief executive officer, has been appointed full-time chairman of the Executive Committee, and Mr. P. Good, for several years deputy director and recently joint-director, has been appointed director and secretary of the Institution. 